\title{
Methodology for Evaluating Innovation Capabilities at University Institutions Using a Fuzzy System
}

\author{
Jakeline Serrano García', Jorge Robledo Velásquez²
}

\begin{abstract}
This article proposes a methodology to evaluate Technological Innovation Capabilities at university institutions, seeking to strengthen innovation management and advance in the integration of said institutions in the dynamics of the innovation system. The Triple Helix Model is adopted to analyze the relationships of university institutions with their surroundings. The proposal is conceptually built on a based on the perspective of resources and capabilities and on to the systemic congruence model of the organization. A fuzzy inference system is developed as the mathematical support of the evaluation process of the Technological Innovation Capabilties. The methodology is experimentally applied to a university institution in Medellín - Colombia, demonstrating its consistency, viability and practical usefulness.
\end{abstract}

Keywords: technological innovation capabilities; fuzzy logic; university institutions; triple helix; organizational congruence model.

\footnotetext{
'Dirección de investigaciones, Instituto Tecnológico Metropolitano. Adress: Calle 73 \# 76A -354 Vía al Volador, Medellín, Colombia. Phone: (574)440 52 6I.Fax: (574) 440 526I.e-mail: jakelineserrano@itm.edu.co; jserrano2005@gmail.com

2Departamento de Ingeniería de la Organización, Facultad de Minas, Universidad Nacional de Colombia, Medellin, Colombia. Phone: (574)425 5200.E-mail: jrobledov@unal.edu.co
} 


\section{Introduction}

The entities responsible for the generation and absorption of most scientific and technological knowledge in Latin America, especially in Colombia, are universities. Their importance regarding the formation of dynamic innovation systems is undeniable. However, few universities develop evaluation processes of their Technological Innovation Capacities to enables the improvement of innovation and development and the application of new technologies, and for linking with the innovation system.

In spite of the importance theoretically given to TICs, a great gap is found in the literature regarding the measurement of these capabilities in the upper education sector of Latin America. This sector mainly aims its institutional development management towards processes of evaluation of quality conditions for access to qualified registries of educational programs, and towards institutional accreditation.

This article proposes a methodology to evaluate the TICs of a university institution ( $\mathrm{UI})$, looking to strengthen innovation management and to advance its relations with the production sector. The methodology enables identifying indicators that clearly define the capabilities needed to dynamize innovation. Conceptually, it is built on the perspective of resources and capabilities, and of a systemic approximation of the organization, following the proposal of Robledo et al (20l0). In this manner, it contributes to the formulation of policies and strategic plans aimed at attaining the innovation objectives of a university institution - as one of the key agents of the dynamics of systemic innovation - effectively covering the demands of the productive sector, of the economy, and of society in general.

The methodology was implemented by means of a fuzzy inference system, structured on the work developed by Medina (2006) based on Kosko (1994) and Jang, Mizutani and Sun (1997).

Presented next are the conceptual bases that support the development of the methodology proposed. Defined afterwards is the methodological model and the fuzzy inference system, to follow with the methodology validation and its experimental application. Finally, the obtained results and analyses are presented, to close with conclusions and recommendations derived from the article.

\section{Innovation and the Triple Helix}

Innovation, therefore a strategy of approximation to it, is essential in all development, growth, sustainability and competitiveness processes. Innovation strategies can be generally characterized in two classes: One centers in companies and concerns about improving their conditions and increasing their innovation capability. The other centers in Higher Education Institutions (HEI), as a link to innovation resulting from knowledge (Carvalho and Etzkowitz, 2008). The fundamental thesis of the Triple Helix. Carvalho and Etzkowitz (2008) argue that knowledge turns into the base of new technologies for industries. The Triple Helix model generates an infrastructure for the articulation of knowledge in the participating institutional entities. The introduction of a Triple Helix changes the rules of the game helping relationships between universities, industry and government transform the development process. This is done through additional interactions over innovation platforms which could be more effective for economic development, social development and environmental sustainability.

Carvalho and Etzkowitz (2008) state that the Triple Helix model in developing countries places HEls in Latin America as the main agents in the creation and diffusion of knowledge. Academic knowledge can be appropriated by an existent company to set up a new business or to improve a product. The Triple Helix model includes the formulation of regional innovation strategies for development. Institutions in this region are created or transformed to help in the transference of knowledge and human resources, and in the creation of spin-offs. They also suggest changes in the legal framework inviting them to participate in the protection of knowledge.

\section{The New Mission and Responsibility of Higher Education with the Innovation System}

Higher education - faced by the proposed challenges of quality, relevance and contribution to development - shall lead a deep reflection about the effects and implications of the new mission, assumed from their responsibility with the dynamics of the innovation system. Therefore it can be stated that for any economy sector, it is fundamental to identify its capability to solve problems and to sustain the economic growth. This depends largely on science, technology and innovation capabilities (Calestous and Cheong, 2005), and in the generation and diffusion of knowledge, a fundamental mission of higher education, without which it is impossible to solve the complex problems of growth and sustainability.

Under this conditions, HEls find another opportunity to contribute to the generation of wealth and wellbeing, based on their scientific and technical developments. Etzkowitz (2003) states: "the entrepreneurial university has the capability to generate a strategic direction focused both in formulating academic goals, as well as in transforming the knowledge produced in the university into social and economic benefits" (p. I I2, author's translation). 
Unfortunately, there are difficulties in the change of paradigm implied by this new perspective. In their studies, Etzkowitz (2003) and Rasmussen, Øystein and Gulbrandsen (2006), found barriers to the change, mainly from professors who argued that the relationships between research and industry groups could deteriorate the basic research of scientists, because the latter would end up devote mainly to applied research.

Debackere and Veugelers (2005) analyze the difficulties of the relationship university-productive sector, possibly observed in many countries. They certify a lack of management and interest from universities and companies to collaborate in innovation dynamics. Colombia is no stranger to this problematic situation, as indicated by Castellanos and Jiménez (2008), in the case of Antioquia (Colombia), Cataño and Botero (2007), show significant research collaboration between business fields, but a scarce one between SMEs (mall and medium enterprises) and knowledge institutions. Currently prevailing in such, according to Abello (2004), is a purely academic culture one, unaware of industry needs.

Evident in front of this panorama is the imperious need for Latin American HEls to aim at long term strategic goals, at creating cultural surroundings favorable to the surging of a variety of new forms of organizations to promote economic and social development, including technological base companies (Carvalho and Etzkowitz, 2008, p. 197). Several countries and a good number of HEls in Latin America have taken significant steps in this direction. In particular, the Colombian government has been working on the promotion and development of science, technology and innovation. Therefore, the strengthening of research and innovation capabilities in higher education institutions is vital for this purpose. Currently, the Ministry of National Education of Colombia and the Administrative Department of Science, Technology and Innovation (COLCIENCIAS) are executing a series of strategic activities aimed at this purpose focusing on: strengthening research capabilities of higher education institutions, strengthening the offer of master's and doctoral programs, technical cooperation and knowledge exchange, improvement of highly qualified human resources, university - society relationship (Sector Plan, 20 I0-20I4).

\section{Congruence Model of Organizational Behavior of Nadler and Tushman (1980)}

One of the proposals conceptually supporting the evaluation methodology of the TICs is the Model of Organizational Congruenceof Nadler and Tushman (1980). upon which the This model is adopted for this paper as the construction formula of organizations aimed at innovation achievement. The authors present four essential components that the organization has, which are designed and structured to be congruent, meaning they couple. The pattern of congruence of the four components, listed below, coincides with the basic requirements of the strategy and the organizational adaptation and efficiency: the tasks (the work that has to be done;) the individuals (the members of the organization;) the formal organization (the formal agreements at the interior of the organization, the structure and the processes adopted so the individuals execute the tasks;) and the informal organization (that which has not been directly formalized and is related to the culture that surges spontaneously and naturally between people that hold positions in the formal organization.)

The model also identifies the inputs, the transformation process, and the outputs, with specific indicators for each area. The inputs are related to environment, resources and organizational history. Afterwards, the strategy provides orientation for the organization to convert the inputs into group, individual and organizational outputs, based on tasks, individuals, formal agreements, and informal organization. In this manner, the model covers all the dimensions that need considering for organizational development in general, and in particular for evaluating their capability to perform in a determined direction.

\section{TICs and their Evaluation}

TICs are defined herein based on various authors working on the perspective of resources and capacities. Cheng et al. (2006) identify them as an intangible company asset. They integrate key resources as technology, production, processes, knowledge, experience and the organization, which are necessary for innovation. On his side, Christensen (1997) classifies them as assets in scientific research, processes innovation, products innovation, design and aesthetics. These assets correlate with the internal and experimental accumulation of company routines. This author sustains that the combination of more than one of these assets is essential for the success of industrial innovation. Azagra et al. (2005) establish that innovation capabilities support the competitive advantages of the companies and involve internal and external aspects by means of cooperation networks with HEls, research units, and technological centers.

In the field of University Institutions, and regarding their participation in the dynamics of the systems of innovation, TICs can be understood as the organizational capabilities sustaining the achievement of institutional innovation objectives, established in the strategic direction. Such capabilities must be identified in each one of the organizational dimensions, to respond and adapt to the constantly changing environment, enabling the linkage of Uls to the system of innovation, and the creation and diffusion of knowledge contributing to technological, economic and social development.

ISSN: 07 I8-2724. (http://www.jotmi.org)

Journal of Technology Management \& Innovation (c) Universidad Alberto Hurtado, Facultad de Economía y Negocios. 


\section{Technological Innovation Capability Classes}

Yam et al. (2004) and Cheng et al. (2006) present seven categories of TICs constituting the basic components of innovation. These were adapted to the context of Uls, in the following manner:

R\&D Capability: organizational skills to creatively generate and apply knowledge and to manage the R\&D and technological transfer portfolio.

Production Capability: organizational skills to transform the results of R\&D into products.

Strategic Planning Capability: organizational skills to formulate and implement innovation policies, programs, and strategies in accordance with the institutional vision and mission.

Organizational Relationship Capability: organizational skills for effective interaction with the actors of the innovation system, in local, national and international settings.

Organizational Learning Capability: organizational skills to manage knowledge and build an organization that learns.

Resource Management Capability: organizational skills to properly manage, acquire and assign resources for innovation development.

Marketing Capability: organizational skills to promote and sell the products of research, and the potential innovations, based on understanding the needs of the community, the costs, the benefits, the competitive surroundings, and the acceptance of innovation.

\section{Evaluation of TICs}

All organizations need to have indicators and conduct periodical evaluations aimed at identifying problems and conducting continuous improvement and transformation processes. Along these lines, the TICs of an organization require a variety of complex indicators, as such cannot be directly measured by any simple parameter (Cheng et al., 2006). It is necessary to specify that the concept of TICs is difficult to determine, and its measurement requires simultaneous consideration of multiple criteria of quantitative and qualitative order, applied to the organization (Wang, Lu and Chen, 2008).

There is an interest in the intensification of innovation measures alongside the development innovation theories.As early as 1962, Simon Kuznets observed that the biggest obstacle for understanding the economic role of technological change, was an evident inability to measure it (Acs, Anselin, and Varga, 2002). The first systematic measures of innovation developed during the $50 \mathrm{~s}$ and $60 \mathrm{~s}$, and focused on the measurement of personnel and on the costs of R\&D. Later on, measures of the results of innovation activities, especially the use of patent data became common as an indicator of innovation activities (Tura and Harmaakorpi, 2005).

However, innovations, as such, are very difficult to quantify and the measurement of the results has generally centered in determined expressions of the successful innovations. The best known indicator of this type of measures is that of "production intervals", such as patents and licenses (Hall, Jaffe and Trajtenberg, 200I). On its side, innovation capability concerns long-term for the talent basis of an economic agent for the innovation performance.Therefore, innovation capability evaluations center in skills, competences and dispositions of an economic agent directly linked to the production of innovations (Tura and Harmaakorpi, 2005).

The central problem to measure technological innovation capabilities is that such are not directly observable or identifiable and, therefore, they are not "operational" by themselves. Because of this, non direct-immediate measurements of innovation capability need to be found (Tura and Harmaakorpi, 2005). Wang, Lu and Chen (2008) state that evaluation models that allow intuitive judgment of technological innovation capabilities have gained acceptance from diverse experts, such as academicians and R\&D industry representatives.

\section{Fuzzy Logic}

Found in many occasions are situations and decision makings in which it is difficult to identify and evaluate the variables that exist in a certain problem, because of the complexity of parameterization, as is the case of qualitative type variables referred to TICs. To use this type of variables it is necessary to use non-traditional models that enable giving a solution to the problem; taking and approximating it to quantitative type variables, converting the problem into a less complex situation.

In specific, models based on moving qualitative to quantitative information are used to measure the description of a situation developed in linguistic terms, to express preferences on attributes, and to translate subjective impressions concerning the variables studied. Topic scholars argue that what is fuzzy, complex or vague, is not the logic as such, but what needs to be quantified. It is here where fuzzy logic finds a suitable application field.

Fuzzy logic appears as a generalization of a multi-value logic that allows reasoning about a world of objects as relational entities (Pedrycz and Gomide, 1998). "It is the logic that

ISSN: 07 I8-2724. (http://www.jotmi.org)

Journal of Technology Management \& Innovation (c) Universidad Alberto Hurtado, Facultad de Economía y Negocios. 
combines input variables defined in terms of concepts and expressions that are not totally true nor totally false, which take any value of veracity in a set of values,"(Medina, 2006, p. 200). It enables treating imprecise information as "medium height", "low temperature" or "a lot of strength", in terms of blurred or fuzzy sets (imprecise, for sure). Said fuzzy sets are combined in rules to define actions. Therefore, control systems based on fuzzy logic by means of rules, produce one or several output values (Martin and Sanz, 2002, p. 245).

A fuzzy logic system: "allows easy use of the knowledge of subject experts, as a starting point for automatic optimization when formalizing the occasionally ambiguous knowledge of an expert (or of common sense) in an attainable form. Additionally, thanks to the simplicity of the necessary calculations (sums and comparisons), they can usually be performed in comfortable, fast systems" (Martin and Sanz 2002, p. 248).

Pedrycz and Gomide (1998) and Medina (2006) highlight that fuzzy logic models are highly flexible, more tolerant to data imprecisions, and can work with non-linear functions of diverse complexity. Likewise, they are not forced by statistical presumptions about data characteristics and their probability distributions. When there is imprecise and insufficient information, the use of statistical tools is not sufficient to obtain significant results. In this manner, this is how fuzzy logic precisely surges to handle this type of problems and be able to give them an optimal solution (Medina, 2006). It is important to highlight that, according to Kosko (1994, quoted by Medina, 2006), a combination between a fuzzy logic system and the experience or knowledge of those in charge of taking decisions, is an excellent way to obtain good results.

\section{Methodological Aspects}

The Methodology Is Divided in Two Stages: The first is derived from the construction of an affinity developed based on the classification of TICs, of authors Yam et al. (2004) and Cheng et al. (2006), and on the dimensions of the organization of Nadler and Tushman (1980) For each organizational dimension and innovation capability, variables were identified, and the evaluation criteria applicable to Uls were analyzed. These variables and evaluation criteria were contrasted with the specialized literature and subjected to validation from a group of selected experts, from four university institutions in the city of Medellin (Colegio Mayor de Antioquia (CMA), Instituto Tecnologico Metropolitano (ITM), Tecnologico de Antioquia (TA) and Politecnico Jaime Isaza Cadavid (PJIC)). The variables were adapted to adjust the model to the particularities of the Uls.

The second stage continued with the design of a fuzzy inference system (FIS), based on the work developed by Medina (2006), based on authors Kosko (1994), and Jang, Mizutani and Sun (1997). The FIS was programmed in an academic version of FuzzyTech $囚$, development software for fuzzy systems based on MS-Windows which allows graphic edition of linguistic variables and optimization of the system using a development based on neural networks. The system used was of the Mamdani type, as it is the one which adjusts better to the problem type of this work, for its particular configuration (blurred and concretion).

The extraction and definition of the input variables was done based on arguments identified through the review

\section{Structure for Capability Assessment}

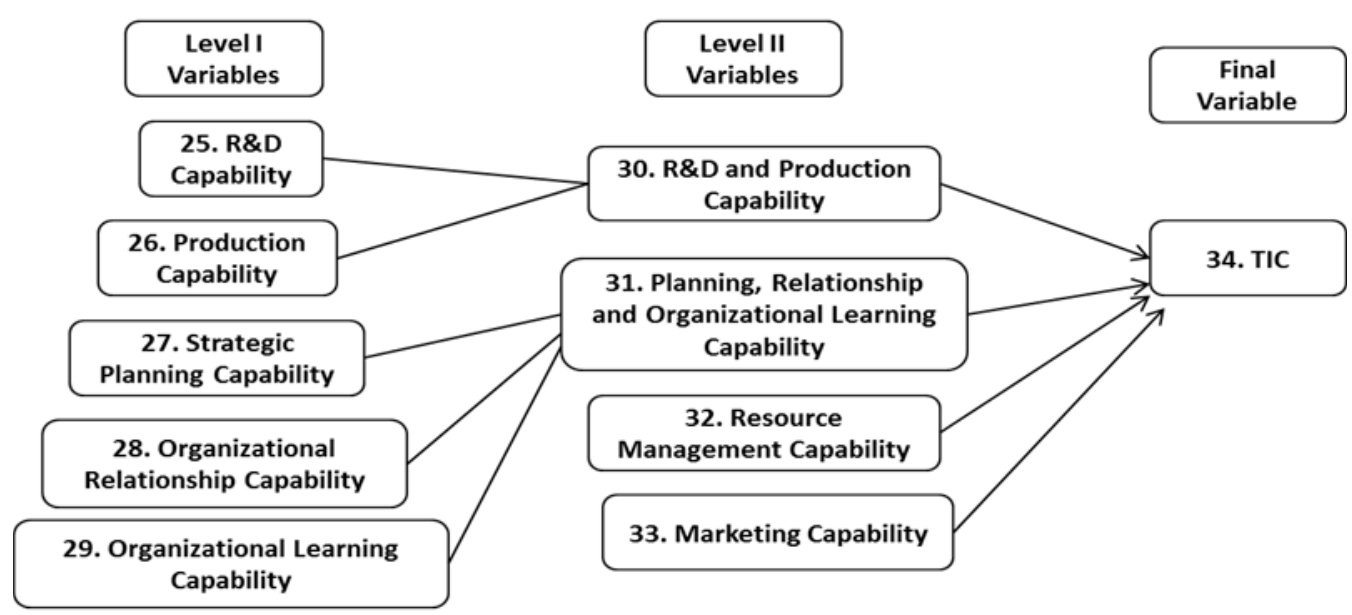

Figure I. Structure for the evaluation of TICs

ISSN: 07I 8-2724. (http://www.jotmi.org)

Journal of Technology Management \& Innovation (c) Universidad Alberto Hurtado, Facultad de Economía y Negocios. 
of different sources of literature. For the calibration of the fuzzy sets of the quantitative / qualitative variables, depending on the case, a grade of valuation given by each expert to each group was used; therefore, no standardized ranks were stipulated. The selected experts assigned values to each fuzzy set of each variable, in accordance to the degree of importance of each one.

A conceptual model for general structure for the evaluation of TICs was formulated based on the final affinity diagram. Said model groups seven capabilities of level I technological innovations with four input variables on average, where each one has three linguistic terms (high, medium, low) associated. In this manner $8 \mathrm{I}$ fuzzy rules are obtained in accordance with the Mandani type system. Meaning: $(n) r$, where $n$ is the number of linguistic terms that exists in each fuzzy set, and $r$ the amount of variables. Then, due to operational limitations of the the FuzzyTech ${ }^{\circledR}$ version used, the first five capabilities of level I are integrated into two capabilities of level II, which along with the other two capabilities of level I, form a system of four related input variables, which allowed obtaining the $8 \mathrm{I}$ fuzzy rules for the evaluation of the final TIC variable. Figure I presents a simplified scheme of the Level I and II variables, and how these are grouped to calculate the final CIT variable.
The description of the process for evaluating R\&D capability at a $\mathrm{Ul}$ is presented in this article. The method is similar for the other capabilities.

Considered for the R\&D variable are three defined and calibrated fuzzy sets, as presented in Table I, represented in FuzzyTech $\circledast$ Figure 2. The following input variables were considered for this variable of level I: VI_Annual percentage for research and innovation; $\mathrm{V} 2$ _Structuring level of the technological management unit, $\mathrm{V} 3$ _ Technological management processes V4_Percentage of professors with masters and doctorates in research.

Tables 2 to 5 , and Figures 3 to 6 define these variables with their respective fuzzy sets, calibrated according to the value ranges taken by each variable in accordance with the opinion and assessment of the experts.

\section{Definition of the knowledge or fuzzy rules}

Table 6 presents the knowledge base corresponding to the R\&D capability variable (level I variable) and its four input variables, built with the expert support by means of the process of scoring proposed by Medina (2010).*

\begin{tabular}{|c|c|c|c|c|c|c|c|c|}
\hline & & \multicolumn{4}{|c|}{ Range } & & & \\
\hline $\begin{array}{c}\text { Variable } 25 . \\
\text { R\&D } \\
\text { Capabilities. }\end{array}$ & $\begin{array}{l}\text { Capabilities. Organizational skills to generate and creatively apply } \\
\text { knowledge and manage the portfolio of R\&D projects and of } \\
\text { technological transfer, referring to four topics: V1_Annual percentage } \\
\text { for research and innovation; V2_Structuring level of the technological } \\
\text { management unit, V3_Technological management processes, and } \\
\text { V4_Percentage of professors with masters and doctorates in research }\end{array}$ & \multicolumn{2}{|c|}{ Minimum } & \multicolumn{2}{|c|}{ Maximum } & \multicolumn{3}{|c|}{ Variable Value Ranges } \\
\hline & & Directo & Author & Directo & Author & Minimum & Average & laximum \\
\hline \multirow{3}{*}{ Fuzzy sets: } & $\begin{array}{l}\text { a. Low: the percentage of the annual budget devoted to research and } \\
\text { innovation is low. There are no policies or programs for the creation of } \\
\text { the technological management unit; lack of processes and procedures } \\
\text { aimed at innovation management and the percentage of professors } \\
\text { with masters and doctorates devoted to research is low. }\end{array}$ & 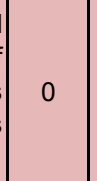 & 0 & 0,3 & 0,5 & 0 & 0,2 & 0,5 \\
\hline & $\begin{array}{l}\text { b. Medium: the percentage of the annual budget devoted to research } \\
\text { and innovation is medium. There is no unit as such but there are clear } \\
\text { policies programs for its creation and maintenance; there are innovation } \\
\text { management practices but they are not defined in process form or the } \\
\text { percentage of professors with masters and doctorates devoted to } \\
\text { research is medium. }\end{array}$ & 0,3 & 0,5 & 0,7 & 0,8 & 0,3 & 0,575 & 0,8 \\
\hline & $\begin{array}{l}\text { c. High: the percentage of the annual budget devoted to research and } \\
\text { innovation is high. It has a consolidated and structured technological } \\
\text { management unit, it has coherent innovation management processes } \\
\text { and procedures and the percentage of professors with masters and } \\
\text { doctorates devoted to research is high. }\end{array}$ & 0,7 & 0,8 & 1 & 1 & 0,7 & 0,875 & 1 \\
\hline
\end{tabular}

Table I. Level I Variable, R\&D Capability

The fuzzy sets associated to the R\&D Capability Variable are presented in Figure $\mathrm{ft}$.

ISSN: 07 I8-2724. (http://www.jotmi.org)

Journal of Technology Management \& Innovation (c) Universidad Alberto Hurtado, Facultad de Economía y Negocios. 


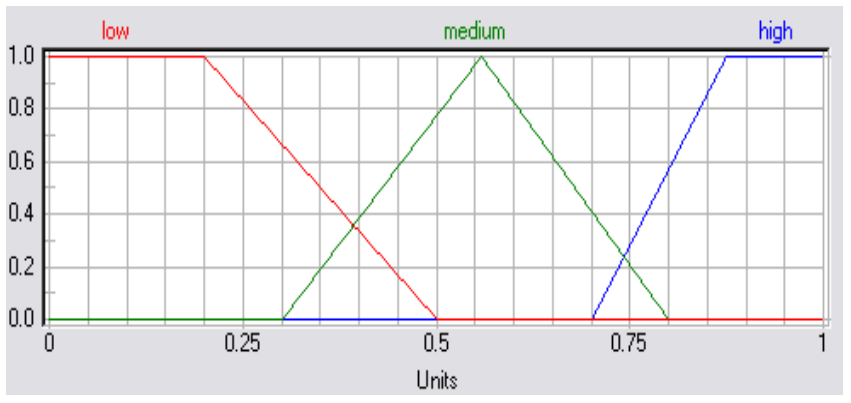

Figure 2. Fuzzy sets of the Level I Variable, R\&D Capability

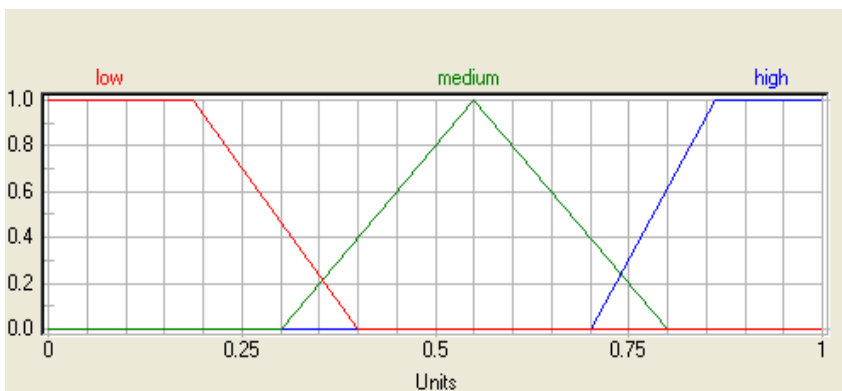

Figure 3. Fuzzy sets of VI, percentage of the annual budget for research and innovation

\begin{tabular}{|c|c|c|c|c|c|c|c|c|c|c|c|c|}
\hline Variable 1 & Percentage of the annual budget & \multicolumn{8}{|c|}{ RANGE } & & & \\
\hline & & \multicolumn{4}{|c|}{ Minimum } & \multicolumn{4}{|c|}{ Maximum } & \multicolumn{3}{|c|}{ Variable Value Ranges } \\
\hline & & E1 JIC & E2 ITM & E3 C MA & E4 T DE A & E1 JIC & E2 IT M & E3 C MA & E4 T DE A & Minimum & Average & Maximum \\
\hline \multirow{3}{*}{ Fuzzy sets } & $\begin{array}{l}\text { a. High: Above what percentage of } \\
\text { the annual budget devoted to } \\
\text { research and innovation is } \\
\text { considered high. }\end{array}$ & 0,7 & 0,8 & 0,7 & 0,7 & 1 & 1 & 1 & 1 & 0,7 & 0,8625 & 1,00 \\
\hline & $\begin{array}{l}\text { b. Medium: Above what percentage } \\
\text { of the annual budget devoted to } \\
\text { research and innovation is } \\
\text { considered medium }\end{array}$ & 0,4 & 0,4 & 0,4 & 0,3 & 0,7 & 0,8 & 0,7 & 0,7 & 0,3 & 0,55 & 0,80 \\
\hline & $\begin{array}{l}\text { c. Low: Until what percentage of the } \\
\text { annual budget devoted to research } \\
\text { and innovation is considered low.. }\end{array}$ & 0 & 0 & 0 & 0 & 0,4 & 0,4 & 0,4 & 0,3 & 0 & 0,1875 & 0,40 \\
\hline & & \multicolumn{4}{|c|}{ Maximum Value } & & & & & & & \\
\hline & & $\mathrm{E} 1 \mathrm{JIC}$ & E2 ITM & E3 C M A & E4 T DE A & Average & & & & & & \\
\hline $\begin{array}{c}\text { Reference } \\
\text { Value }\end{array}$ & $\begin{array}{l}\text { 1. Indicate the maximum percentage } \\
\text { of the annual budget that a university } \\
\text { institution of excellence would invest } \\
\text { in research and innovation. }\end{array}$ & $13 \%$ & $15 \%$ & $10 \%$ & $15 \%$ & $13 \%$ & & & & & & \\
\hline
\end{tabular}

Table 2.VI, Percentage of the annual budget for research and innovation

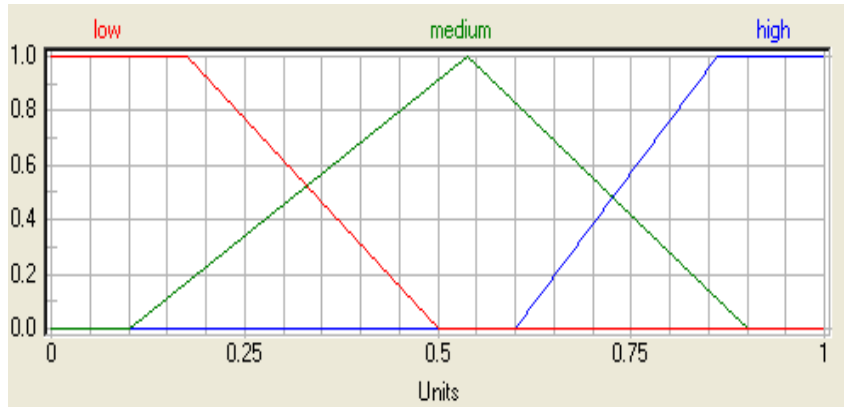

Figure 4. Fuzzy sets of V2, level of structuring of the technological management unit

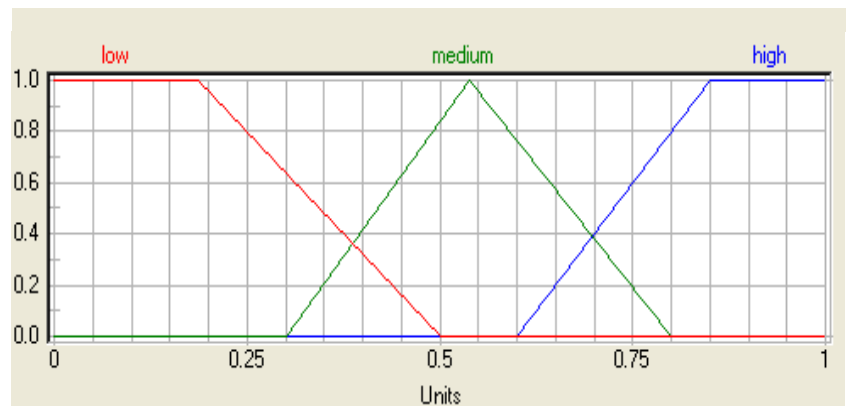

Figure 5. Fuzzy sets of Input Variable 3, technological management processes

ISSN: 07 I8-2724. (http://www.jotmi.org)

Journal of Technology Management \& Innovation (c) Universidad Alberto Hurtado, Facultad de Economía y Negocios. 


\begin{tabular}{|c|c|c|c|c|c|c|c|c|c|c|c|c|}
\hline \multirow[t]{3}{*}{ Variable 2.} & $\begin{array}{l}\text { Level of structuring and hierarchical } \\
\text { importance given to the technological } \\
\text { management unit and to the bodies } \\
\text { responsible for the extension. This } \\
\text { unit leads and promotes the } \\
\text { university and its research groups } \\
\text { towards technological development } \\
\text { and creates links with the productive } \\
\text { sector }\end{array}$ & \multicolumn{8}{|c|}{ RANGE } & & & \\
\hline & & \multicolumn{4}{|c|}{ Minimum } & \multicolumn{4}{|c|}{ Maximum } & \multicolumn{3}{|c|}{ Variable Value Ranges } \\
\hline & & $\mathrm{E} 1 \mathrm{JIC}$ & $\mathrm{E} 2$ I T M & E3 C MA & E4 T DE A & $\mathrm{E} 1 \mathrm{JIC}$ & E2 ITM & E3 C MA & E4 T DE A & Minimum & Average & Maximum \\
\hline \multirow{3}{*}{ Fuzzy sets: } & $\begin{array}{l}\text { a. High: the unit is consolidated and } \\
\text { structured. It has direct } \\
\text { representation in the University } \\
\text { Academic Council or equivalent }\end{array}$ & 0,7 & 0,6 & 0,9 & 0,7 & 1 & 1 & 1 & 1 & 0,6 & 0,8625 & 1,00 \\
\hline & $\begin{array}{l}\text { b. Medium: the unit does not exist } \\
\text { as such but there are clear } \\
\text { management policies for its creation } \\
\text { and maintenance. }\end{array}$ & 0,4 & 0,1 & 0,5 & 0,4 & 0,7 & 0,6 & 0,9 & 0,7 & 0,1 & 0,5375 & 0,90 \\
\hline & $\begin{array}{l}\text { c. Low: the unit does not exist, and } \\
\text { there are no intentions for policies } \\
\text { and procedures leading to its } \\
\text { creation }\end{array}$ & 0 & 0 & 0 & 0 & 0,4 & 0,1 & 0,5 & 0,4 & 0 & 0,175 & 0,50 \\
\hline
\end{tabular}

Table 3.V2, Level of structuring of the technological management unit

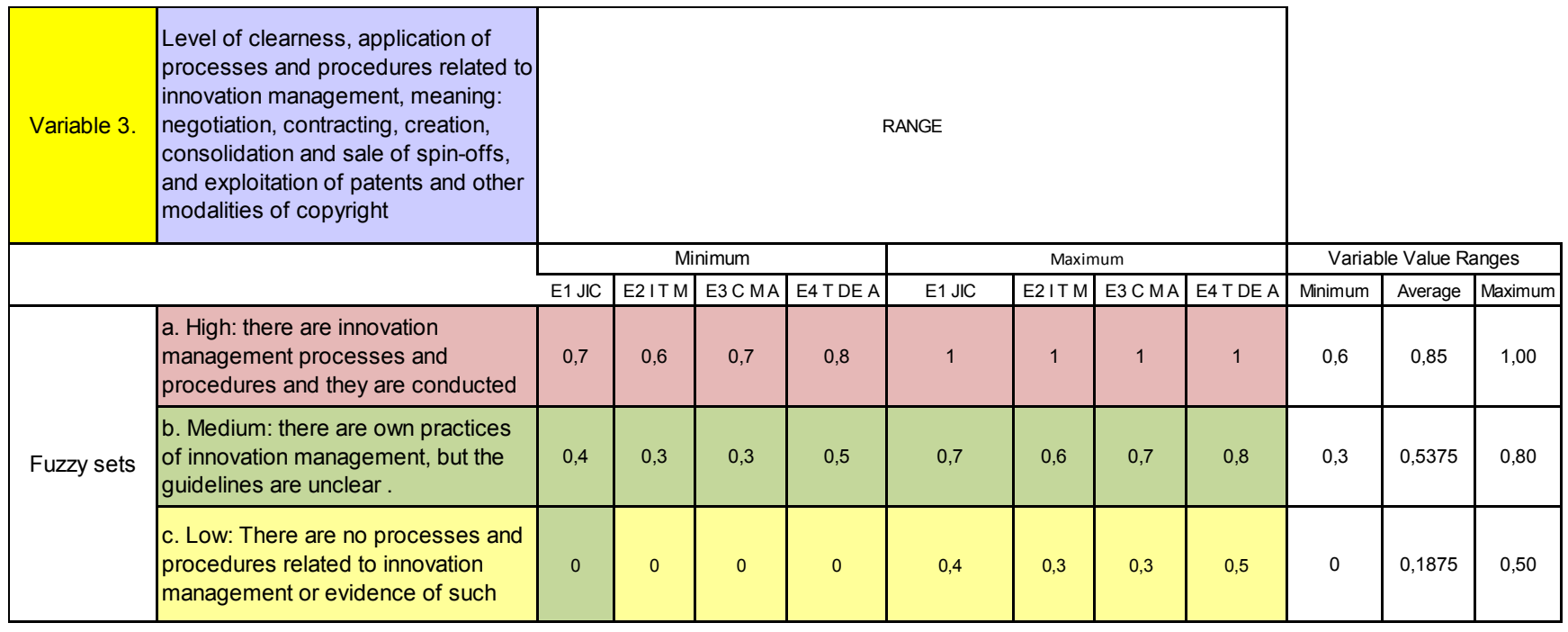

Table 4.V3, Technological management processes

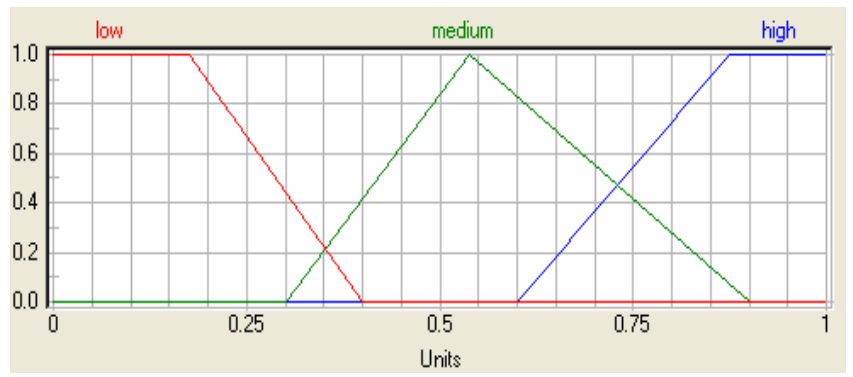

Figure 6. Fuzzy sets of V4, percentage of professors with masters and doctorates in research

ISSN: 07 I8-2724. (http://www.jotmi.org)

Journal of Technology Management \& Innovation (c) Universidad Alberto Hurtado, Facultad de Economía y Negocios. 


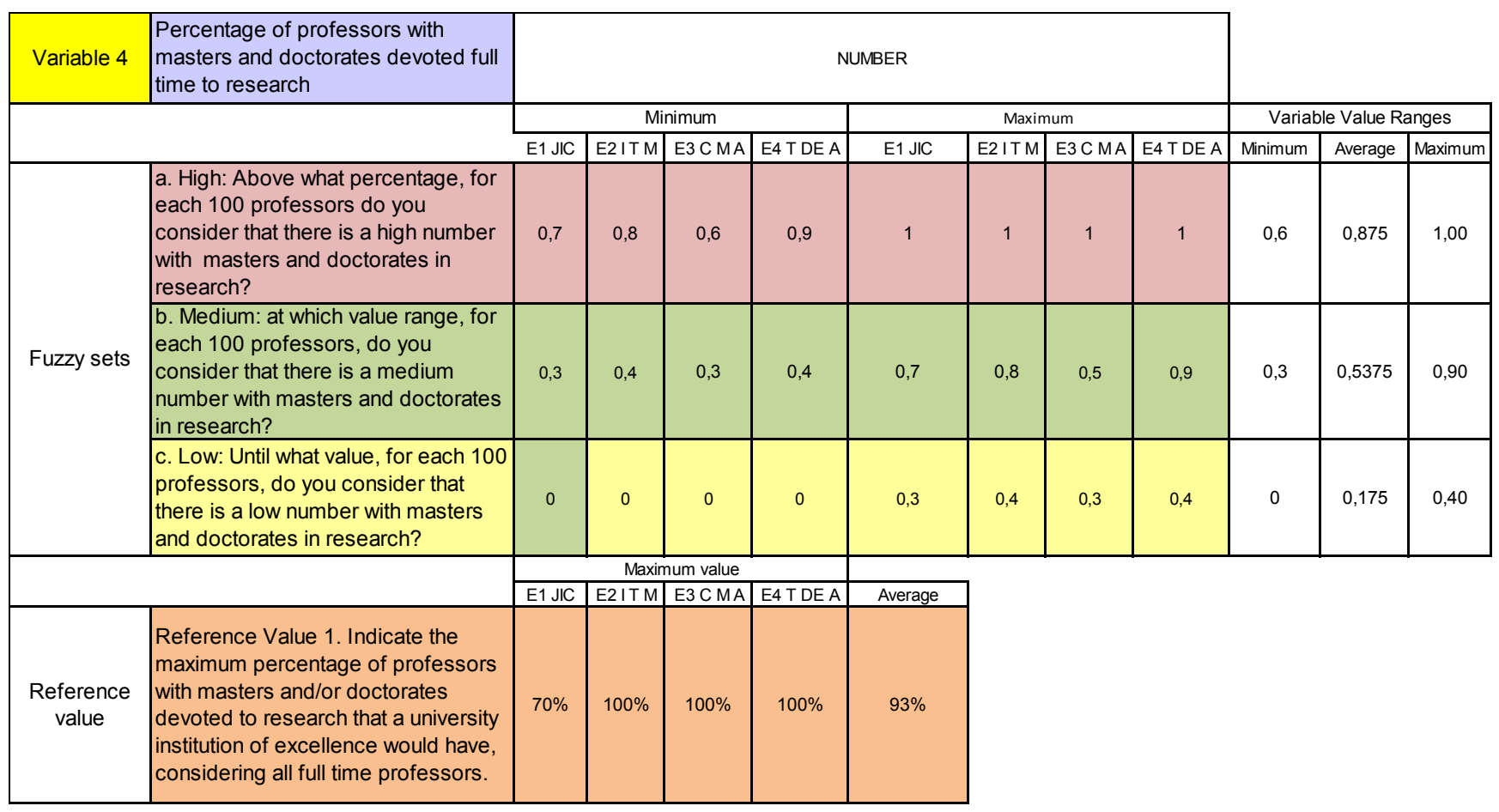

Table 5.V4, Percentage of professors with masters and doctorates in research

\begin{tabular}{|c|c|c|c|c|c|c|c|c|c|c|c|c|c|c|c|c|c|c|c|c|c|c|c|c|c|c|c|c|c|c|}
\hline \multicolumn{2}{|c|}{$\begin{array}{c}\text { Weight } \\
\text { Average } \\
\text { Variable } 1\end{array}$} & \multicolumn{2}{|c|}{$\begin{array}{c}\text { Weight } \\
\text { Average } \\
\text { Variable } 2\end{array}$} & \multicolumn{7}{|c|}{ Weight Average variable 4} & & & \multirow{2}{*}{\multicolumn{2}{|c|}{ Maximum }} & \multirow{2}{*}{\multicolumn{2}{|c|}{0,57}} & & & & & & & & & & & & & & \\
\hline \multirow{3}{*}{\multicolumn{2}{|c|}{0,2}} & \multirow{3}{*}{\multicolumn{2}{|c|}{0,3}} & & & & & $y$ sets av & erage & & & & & & & & & & & & & & & & & & & & & \\
\hline & & & & 0,2 & 0,28 & 0,52 & 0,2 & 0,28 & 0,52 & \begin{tabular}{|l|}
0,2 \\
\end{tabular} & 0,28 & 0,52 & \multirow{2}{*}{\multicolumn{2}{|c|}{ Minimum }} & \multirow{2}{*}{\multicolumn{2}{|c|}{0,11}} & & & & & & & & & & & & & & \\
\hline & & & & Low & Medium & High & Low & Medium & High & Low & Medium & High & & & & & & & & & & & & & & & & & & \\
\hline \multirow{4}{*}{\multicolumn{2}{|c|}{$\begin{array}{l}\text { Average Fuzzy } \\
\text { sets }\end{array}$}} & \multirow{4}{*}{\multicolumn{2}{|c|}{$\begin{array}{l}\text { Average Fuzzy } \\
\text { sets }\end{array}$}} & \multicolumn{7}{|c|}{ Weight Average variable 3} & 0 & & \multirow{2}{*}{\multicolumn{2}{|c|}{ Amplitude }} & \multirow{2}{*}{\multicolumn{2}{|c|}{0,11}} & & & & & & & & & & & & & & \\
\hline & & & & \multicolumn{9}{|c|}{ Average Fuzzy sets } & & & & & & & & & & & & & & & & & & \\
\hline & & & & 0,08 & 0,08 & 0,08 & 0,25 & 0,25 & 0,25 & 0,67 & 0,67 & 0,67 & Fact. & 0,8 & Lim min & 0,21 & & & & & & 1 & 2 & 3 & 4 & 5 & 6 & 7 & 8 & 9 \\
\hline & & & & Low & Low & Low & Medium & Medium & Medium & High & High & High & Fact. & 1,8 & $\operatorname{Lim}_{\max }$ & 0,32 & & & & & & \multicolumn{9}{|c|}{ Validation } \\
\hline 0,08 & Low & 0,05 & Low & 0,11 & 0,14 & 0,23 & 0,14 & 0,17 & 0,25 & 0,19 & 0,22 & 0,3 & Low & Low & Medium & Low & Low & Medium & Low & Medium & Medium & Low & Low & Medium & Low & Low & High & Low & Medium & High \\
\hline 0,27 & Medium & 0,05 & Low & 0,15 & 0,18 & 0,27 & 0,17 & 0,2 & 0,29 & 0,23 & 0,26 & 0,34 & Low & Low & Medium & Low & Low & Medium & Medium & Medium & High & & & & & & & & & \\
\hline 0,65 & High & 0,05 & Low & 0,23 & 0,26 & 0,34 & 0,25 & 0,28 & 0,36 & 0,3 & 0,33 & 0,42 & Medium & Medium & High & Medium & Medium & High & Medium & High & High & Low & Medium & High & Medium & Medium & High & Medium & High & High \\
\hline 0,08 & Low & 0,4 & Medium & 0,22 & 0,25 & 0,33 & 0,24 & 0,27 & 0,36 & 0,3 & 0,33 & 0,41 & Medium & Medium & High & Medium & Medium & High & Medium & High & High & & & & & & & & & \\
\hline 0,27 & Medium & 0,4 & Medium & 0,26 & 0,29 & 0,37 & 0,28 & 0,31 & 0,39 & 0,33 & 0,36 & 0,45 & Medium & Medium & High & Medium & Medium & High & High & High & High & Medium & Medium & High & Medium & Medium & High & High & High & High \\
\hline 0,65 & \begin{tabular}{|l} 
High \\
\end{tabular} & 0,4 & \begin{tabular}{|l|l|} 
Medium \\
\end{tabular} & 0,33 & 0,36 & 0,45 & 0,35 & 0,38 & \begin{tabular}{|l|}
0,47 \\
\end{tabular} & 0,41 & 0,44 & 0,52 & \begin{tabular}{|l|l|} 
High \\
\end{tabular} & \begin{tabular}{|l|} 
High \\
\end{tabular} & \begin{tabular}{|l|l|} 
High \\
\end{tabular} & \begin{tabular}{|l} 
High \\
\end{tabular} & \begin{tabular}{|l|} 
High \\
\end{tabular} & \begin{tabular}{|l|l} 
High \\
\end{tabular} & \begin{tabular}{|l|l} 
High \\
\end{tabular} & High & \begin{tabular}{|l|l} 
High \\
\end{tabular} & & & & & & & & & \\
\hline 0,08 & Low & 0,55 & High & 0,26 & 0,29 & 0,38 & 0,29 & 0,32 & 0,4 & 0,34 & 0,37 & 0,45 & Medium & Medium & High & Medium & Medium & High & High & High & High & Low & Medium & High & Medium & Medium & High & Medium & High & High \\
\hline 0,27 & Medium & 0,55 & High & 0,3 & 0,33 & 0,42 & 0,32 & 0,35 & 0,44 & 0,38 & 0,41 & 0,49 & Medium & High & High & High & High & High & High & High & High & & & & & & & & & \\
\hline 0,65 & \begin{tabular}{|l|} 
High \\
\end{tabular} & 0,55 & High & 0,38 & 0,41 & 0,49 & 0,4 & 0,43 & \begin{tabular}{|l|}
0,51 \\
\end{tabular} & 0,45 & 0,48 & 0,57 & \begin{tabular}{|l|} 
High \\
\end{tabular} & \begin{tabular}{|l|l|} 
High \\
\end{tabular} & \begin{tabular}{|l|} 
High \\
\end{tabular} & High & \begin{tabular}{|l|l|} 
High \\
\end{tabular} & \begin{tabular}{|l|} 
High \\
\end{tabular} & High & High & High & IMedium & High & High & $\mid$ Medium & High & High & \begin{tabular}{|l|l|} 
High \\
\end{tabular} & \begin{tabular}{|l|l} 
High \\
\end{tabular} & High \\
\hline
\end{tabular}

Table 6. Base of knowledge corresponding to the R\&D Capability Variable.

ISSN: 07 I8-2724. (http://www.jotmi.org)

Journal of Technology Management \& Innovation (c) Universidad Alberto Hurtado, Facultad de Economía y Negocios. 


\begin{tabular}{|c|c|c|c|c|c|c|c|c|c|c|}
\hline \multirow[t]{2}{*}{ INPUT VARIABLES } & \multicolumn{4}{|c|}{$\begin{array}{l}\text { Weigh of importance or effect } \\
\text { upon the output variable }\end{array}$} & \multirow[t]{2}{*}{ FUZZY SETS } & \multicolumn{4}{|c|}{$\begin{array}{c}\text { Weight of each set, and } \\
\text { indicate the effect on the input } \\
\text { and output variable }\end{array}$} & \multirow[t]{2}{*}{ LEVEL IVARIABLE } \\
\hline & Average & ITM & CMA & TDEA & & Average & ITM & CMA & TDEA & \\
\hline \multirow{3}{*}{$\begin{array}{l}\text { VARIABLE } 1 . \\
\text { Percentage of the annual } \\
\text { budget devoted to } \\
\text { research and innovation. }\end{array}$} & \multirow{3}{*}{$20 \%$} & \multirow{3}{*}{$20 \%$} & \multirow{3}{*}{$20 \%$} & \multirow{3}{*}{$20 \%$} & $\begin{array}{l}\text { a. Low: Until what percentage of the } \\
\text { annual budget devoted to research and } \\
\text { innovation is considered low? }\end{array}$ & $8 \%$ & $10 \%$ & $10 \%$ & $5 \%$ & \multirow{16}{*}{$\begin{array}{c}\text { R\&D } \\
\text { Capabilities. } \\
\text { Organizational } \\
\text { skills to } \\
\text { generate and } \\
\text { creatively apply } \\
\text { knowledge and } \\
\text { manage the } \\
\text { portfolio of } \\
\text { R\&D projects } \\
\text { and of } \\
\text { technological } \\
\text { transfer. }\end{array}$} \\
\hline & & & & & $\begin{array}{l}\text { b. Medium: above what value range do } \\
\text { you consider the percentage of the } \\
\text { annual budget devoted to research and } \\
\text { innovation medium? }\end{array}$ & $27 \%$ & $20 \%$ & $30 \%$ & $30 \%$ & \\
\hline & & & & & $\begin{array}{l}\text { c. High: Above what percentage of the } \\
\text { annual budget devoted to research and } \\
\text { innovation is considered high. }\end{array}$ & $65 \%$ & $70 \%$ & $60 \%$ & $65 \%$ & \\
\hline & & & & & & $100 \%$ & $100 \%$ & $100 \%$ & $100 \%$ & \\
\hline \multirow{4}{*}{$\begin{array}{l}\text { VARIABLE 2. Level of } \\
\text { structuring and } \\
\text { hierarchical importance } \\
\text { given to the } \\
\text { technological } \\
\text { management unit and to } \\
\text { the bodies responsible } \\
\text { for the extension. This } \\
\text { unit leads and promotes } \\
\text { the university and its } \\
\text { research groups towards } \\
\text { technological } \\
\text { development and } \\
\text { creating links with the } \\
\text { productive sector }\end{array}$} & \multirow{3}{*}{$30 \%$} & \multirow{3}{*}{$30 \%$} & \multirow{3}{*}{$25 \%$} & \multirow{3}{*}{$36 \%$} & $\begin{array}{l}\text { a. Low: the unit does not exist, and there } \\
\text { are no intentions for policies and } \\
\text { procedures leading to its creation. }\end{array}$ & $5 \%$ & $10 \%$ & $0 \%$ & $5 \%$ & \\
\hline & & & & & $\begin{array}{l}\text { b. Medium: the unit does not exist as } \\
\text { such but there are clear management } \\
\text { policies for its creation and maintenance. }\end{array}$ & $40 \%$ & $40 \%$ & $40 \%$ & $40 \%$ & \\
\hline & & & & & $\begin{array}{l}\text { c. High: The unit is consolidated and } \\
\text { structured. It has direct representation in } \\
\text { the University Academic Council or } \\
\text { equivalent body. }\end{array}$ & $55 \%$ & $50 \%$ & $60 \%$ & $55 \%$ & \\
\hline & & & & & & $100 \%$ & $100 \%$ & $100 \%$ & $100 \%$ & \\
\hline \multirow{4}{*}{\begin{tabular}{|l|} 
VARIABLE 3. Level of \\
clearness, application of \\
processes and \\
procedures related to \\
innovation management, \\
meaning: negotiation, \\
contracting, creation, \\
consolidation and sale of \\
spin-offs, and \\
exploitation of patents \\
and other modalities of \\
copyright
\end{tabular}} & \multirow{3}{*}{$13 \%$} & \multirow{3}{*}{$15 \%$} & \multirow{3}{*}{$15 \%$} & \multirow{3}{*}{$10 \%$} & $\begin{array}{l}\text { a. Low: There are no processes and } \\
\text { procedures related to innovation } \\
\text { management nor evidence of such }\end{array}$ & $8 \%$ & $10 \%$ & $0 \%$ & $15 \%$ & \\
\hline & & & & & $\begin{array}{l}\text { b. Medium: there are own practices of } \\
\text { innovation management, but the } \\
\text { guidelines are unclear. }\end{array}$ & $25 \%$ & $20 \%$ & $30 \%$ & $25 \%$ & \\
\hline & & & & & $\begin{array}{l}\text { c. High: there are innovation } \\
\text { management processes and procedures } \\
\text { and they are conducted. }\end{array}$ & $67 \%$ & $70 \%$ & $70 \%$ & $60 \%$ & \\
\hline & & & & & & $100 \%$ & $100 \%$ & $100 \%$ & $100 \%$ & \\
\hline \multirow{3}{*}{$\begin{array}{l}\text { VARIABLE } 4 . \\
\text { Percentage of } \\
\text { professors with masters } \\
\text { and doctorates, devoted } \\
\text { full time to research. }\end{array}$} & \multirow{3}{*}{$36 \%$} & \multirow{3}{*}{$35 \%$} & \multirow{3}{*}{$40 \%$} & \multirow{3}{*}{$34 \%$} & $\begin{array}{l}\text { a. Low: Until what value, for each } 100 \\
\text { professors, do you consider that there is } \\
\text { a low number with masters and } \\
\text { doctorates in research }\end{array}$ & $20 \%$ & $20 \%$ & $20 \%$ & $20 \%$ & \\
\hline & & & & & $\begin{array}{l}\text { b. Medium: at which value range, for } \\
\text { each } 100 \text { professors, do you consider } \\
\text { that there is a medium number } \\
\text { with masters and doctorates in research? }\end{array}$ & $28 \%$ & $30 \%$ & $25 \%$ & $30 \%$ & \\
\hline & & & & & $\begin{array}{l}\text { c. High: above what percentage, for } \\
\text { each } 100 \text { professors, do you consider } \\
\text { that there is a high number with masters } \\
\text { and doctorates in research? }\end{array}$ & $52 \%$ & $50 \%$ & $55 \%$ & $50 \%$ & \\
\hline & $100 \%$ & $100 \%$ & $100 \%$ & $100 \%$ & & $100 \%$ & $100 \%$ & $100 \%$ & $100 \%$ & \\
\hline
\end{tabular}

*Definition of the knowledge or fuzzy rules

Table 6 presents the knowledge base corresponding to the R\&D capability variable (level I variable) and its four input variables, built with the expert support by means of the process of scoring proposed by Medina (2010).

ISSN: 07 I8-2724. (http://www.jotmi.org)

Journal of Technology Management \& Innovation (c) Universidad Alberto Hurtado, Facultad de Economía y Negocios. 


\section{Validation of Methodological Proposal}

The validation of the methodology used to evaluate TICs in a UI consisted of four steps:

a) The ranges applied to the variables and the verification of the methodology were developed by means of queries to a panel of experts from different university institutions of the city of Medellin, Colombia, who assigned the assessment and degree of importance of the fuzzy sets, and contributed to the definition of the knowledge base or fuzzy rules;

b) The proof of desk, which presented high, medium and low scenarios for verifying the proposal's internal consistency, departing from contrast with topic literature and a simulation of the methodology to verify that its functionality corresponded to the projection;

c) The experimental application of the methodology was conducted at a UI of the city of Medellin, involving a group of directors, deans and professors. Consensus on the condition of the Ul with regards to the evaluation of each one of the variables was reached through a tool for TIC diagnosis. From the consensus, the normalization of each one of the variables proceeded in accordance with the opinions and indicators of the experts. These were applied to the fuzzy logic process developed, to generate the concretion of the final variable. In other words: to generate numeric results;

d) Analysis of results from the methodology's experimental application. The analysis of the R\&D capability was done based on four variables representing key components of the capability:VI_percentage of annual budget for research and innovation; V2_Structuring level of the technological management unit; $\mathrm{V} 3$ _Technological management processes; and V4_Percentage of professors with masters and doctorates in research.

Figure 7 presents the crisp value, and Table 7 presents the validation of the knowledge base of R\&D capability.

Graph I shows the response surface of the fuzzy inference system for R\&D Capability of the UI, locating this capability in a medium level with a value of $55.75 \%$. It shows the dependency of R\&D Capability with regards to two strategic variables selected in accordance to the weight and importance provided by the experts. They are: $\mathrm{V} 2$ _ technological management unit,V4_Percentage of professors with masters and doctorates dedicated to research.

Observed in Graph I is a R\&D Capability of $55 \%$ for the $\mathrm{UI}$, with a structuring level of the technological management unit of $50 \%$, and a $34 \%$ of professors with masters and doctorates in research.
If the institution increased the structuring level of the technological management unit from $50 \%$, leaving the percentage of professors with masters and doctorates in research untouched at a level of $34 \%$, its R\&D Capability would remain locked in a level of $55 \%$.

If the institution increased the percentage of professors with masters and or doctorates devoted to research from $34 \%$ to $64 \%$, leaving its structuring level of the technological management unit untouched at 50\%, its R\&D Capability would remain at a level of $55 \%$. To improve it, it is necessary to increase the percentage of professors from $64 \%$ to at least $90 \%$ and, in this manner, reach a maximum of $94 \%$ in R\&D Capability.

\section{Conclusions}

The methodology to evaluate TICs at a University Institution presented here is proposed as a novel administrative tool, articulated with five dimensions and seven organizational capabilities. The models's strategic variables were identified based on bibliographic review, and were selected and calibrated based on the knowledge and experience of experts from university institutions, considering the projection of said institutions towards excellence in the field of science, technology and innovation.

TICs are of quantitative, qualitative and multidimensional types. Therefore, a fundamental tool was found in fuzzy logic to evaluate the variables identified. Thus, the methodology developed from the design of a fuzzy inference system enabled the intervention and productive participation of experts from different university institutions. They offered information for the evaluation of ranges and the importance of each one of the variables, when providing linguistic evaluations instead of exact numerical values. Consequently, it was understood that that the combination between a fuzzy logic system and the experience and knowledge of experts, is an excellent way to obtain good results and, therefore, good support for taking decisions.

When conducting the preliminary validation, by means of the experimental application of the tool to the university institution, the benefits of the diagnosis of TICs were indentified. Likewise, the possibility of applying the methodology to any UI, given the generality of the variables evaluated, was also identified.

The methodology is valued as a management tool that contributes to the knowledge, the vision, and the sensitization about the need of Uls to formulate and implement policies, strategies, and action plans that strengthen their capability to contribute and successfully insert themselves in the processes supporting the regional innovation system.

\section{Acknowledgements}

The authors would like to acknowledge the UI where the methodology was experimentally applied, and Universidad Nacional de Colombia, Sede Medellin [National University of Colombia, Medellin Site] for the support given for the 


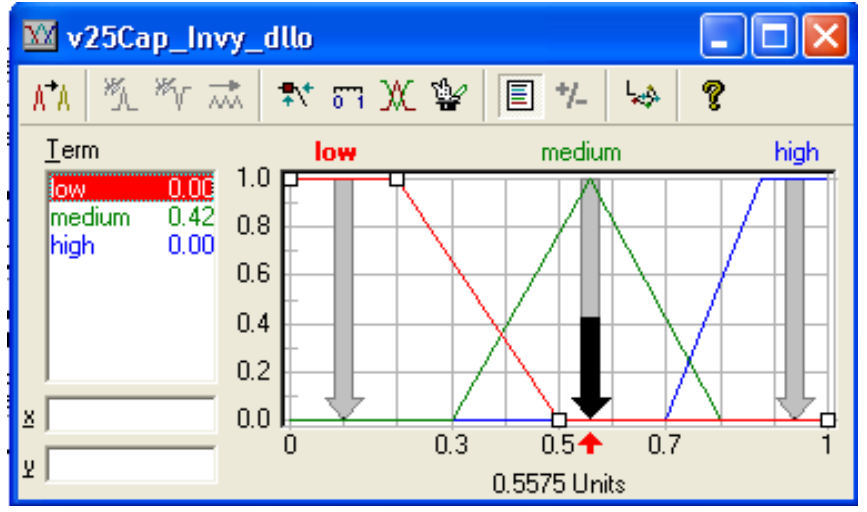

Figure 7. Grading of R\&D Capability

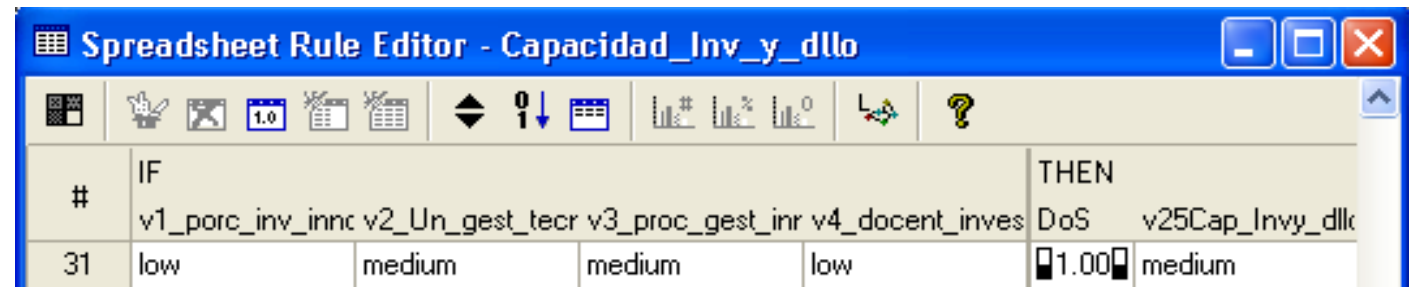

Table 7. Base of knowledge R \& D Capability Validation

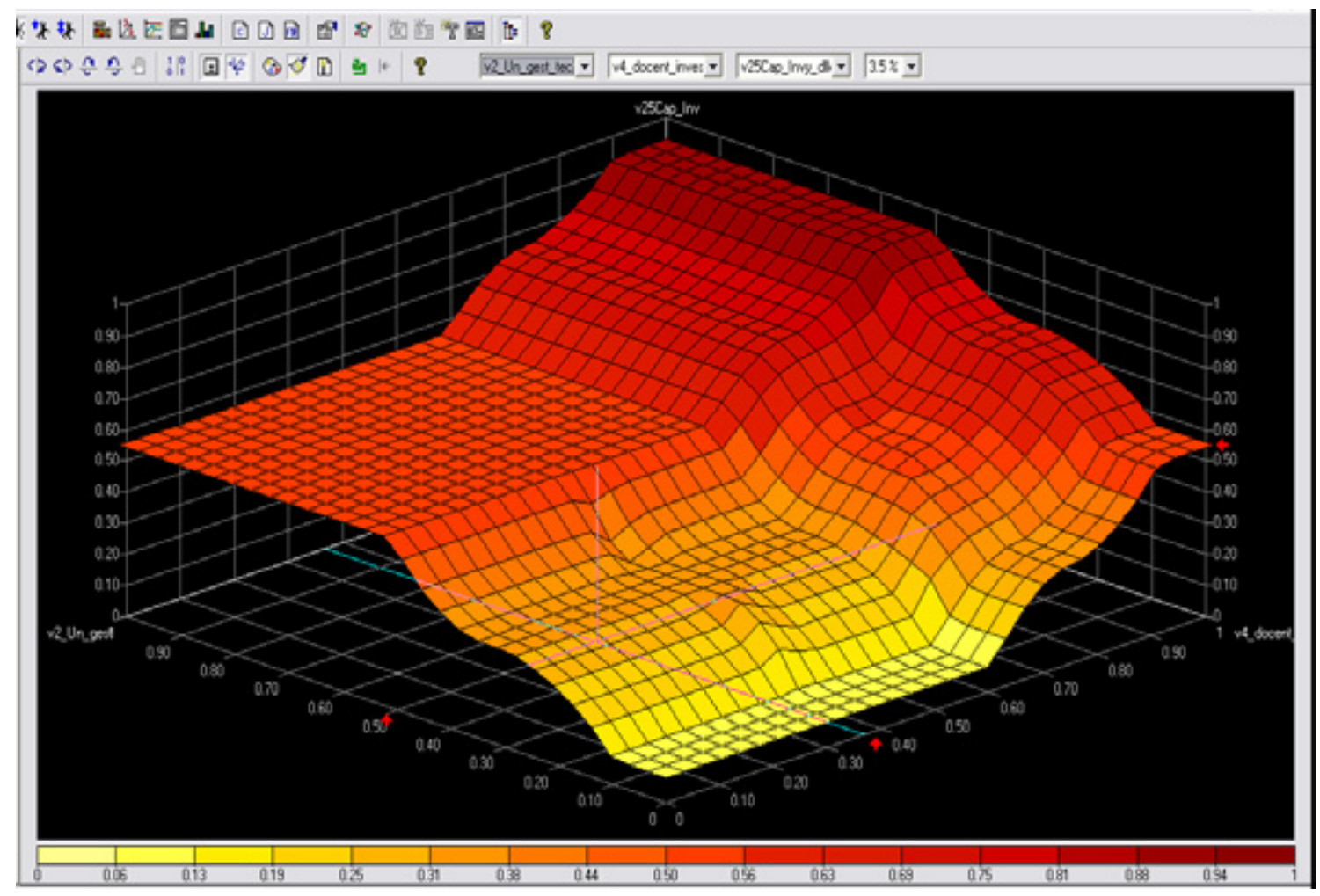

Graph I. R\&D Capability vs V2_Structuring level of the technological management unit andV4_Percentage of professors with masters and doctorates in research. 
development of this research.A special acknowledgement is deserved by UI directors and professors who participated in the exercise of experimental validation of the methodology. Likewise, the authors acknowledge Professor Santiago Medina Hurtado for his advice in the Application of fuzzy logic, and experts Néstor Raúl Pérez Jaramillo, Jorge Iván Brand Ortiz, Jorge Iván Correa Alzate and Fredy Mauricio Gutiérrez, whose contribution to the calibration and validation of the methodological model was fundamental for the development of the project.

\section{References}

ABELLO, R. 2004. La universidad: un factor clave para la innovación tecnológica empresarial. Pensamiento y gestión, Universidad del Norte, Colombia, 16, 28 - 42.

ACS, Z., Anselin, L. y Varga, A. 2002. Patents and innovation counts as measures of regional production of new knowledge. Research Policy, 3I, I069-1085.

AZAGRA, M., Fragiskos, A., Gutiérrez, A. y Gracia, I. 2005. Faculty support for the objectives of university-industry relations versus degree of R\&D cooperation:The importance of regional absorptive capability. Research Policy, 35, 37-55. Ministerio De Educación Nacional De Colombia. 2010. Plan Sectorial 2010-20 I4, Bogotá-Colombia, I-I I0.

CALESTOUS, J. y Cheong, L. 2005. Task force on science, technology, and innovation. An millenniumproject 2005. Innovation:Applying Knowledge in Development.

CARVALHO, J.y Etzkowitz, H. 2008. New directions in Latin American university-industry-government Interactions. International Journal of Technology Management and Sustainable Development, 3, 193-204.

CASTELLANOS, O. y Jiménez, C. 2008. Desafíos en gestión tecnológica para las Universidades como generadoras de conocimiento. I Congreso Internacional de Gestión Tecnológica e Innovación, Bogotá - Colombia.

CATAÑO, G. y Botero P. 2007. Las Pymes: vínculos y redes de cooperación para la innovación en Antioquia, (un estudio en exploración). Revista Tecno-lógicas, I 8, I I-42.

CHENG, J., Yam, R., Kam, C., y Ma, N. 2006. A study of the relationship between competitiveness and technological innovation capability based on DEA models. European Journal of Operational Research, I70, 97I-986.

CHRISTENSEN, C. 1997. Making strategy: learning by doing. Harvard Business Review, 75(6), I4I-I56.
DEBACKERE, K. y Veugelers R. 2005. The role of academic technology transfer organizations in improving industry science links. Research Policy, 34, 32 I-342.

ETZKOWITZ, H. 2003. Research groups as 'quasi-firms': the invention of the entrepreneurial university. Research Policy, $32,109-121$.

HALL, B., Jaffe, A. y Trajtenberg, M. 200I. The NBER patent citations data file: lessons, insights and methodological tools. WP 8498 National Bureau of Economic Research.

KOSKO, B. 1994. Fuzzy systems as universal approximators. IEEE Transactions on Computers, 43, I329-1333.

JANG, J., Mizutani, E. Y Sun, C. 1997. Neuro-fuzzy and soft computing: A computational approach to learning and machine intelligence. New York: Prentice Hall,

MARTÍN, B. \& Sanz, A. 2002. Redes neuronales y sistemas difusos. México, D. F.,Alfaomega Grupo Editor.

MEDINA, S. 2006. Estado de la cuestión acerca del uso de la lógica difusa en problemas financieros. Universidad Javeriana, Cuadernos Administración, 19, 195 - 223,

MEDINA, S. 2010. Modeling of operative risk using fuzzy expert systems. En M. Glykas (Ed.), Fuzzy Cognitive Maps Advances in Theory, Methodologies, Tools and Applications. Chios, Greece: Editorial Spinger, University of Aegean.

NADLER, D. y Tushman, M. 1980. A model for diagnosing organizational behavior. Organizational Dynamics, 35-5I.

PEDRYCZ, W. y Gomide, F. 1998. An introduction to fuzzy sets, analysis and design. Cambrigde, Massachusetts, The MIT Press.

RASMUSSEN, E., Øystein, M., y Gulbrandsen, M. 2006. Initiatives to promote commercialization of university knowledge. Technovation, 26, 5I8-533.

ROBLEDO, J., López, C., Zapata,W., Pérez, J.D. 20 I0. Desarrollo de una metodología de evaluación de capacidades de innovación, Revista Perfil de Coyuntura Económica, agosto $2010,15,133-148$.

SERRANO,J.20I0. Metodología para evaluar las capacidades de innovación tecnológica en una institución universitaria utilizando un sistema difuso, tesis de grado para optar al título de Magíster en Ingeniería Administrativa. Universidad Nacional de Colombia Sede Medellín. 
TURA, T. y Harmaakorpi,V. 2005. Measuring regional innovative capability. 45th Congress of the European Regional Science Association Amsterdam, Netherlands, 23-27.

WANG, C. y Chuu, J. 2004. Group decision-making using a fuzzy linguistic approach for evaluating the flexibility in a manufacturing system. European Journal of Operational Research, I54, 563-572,

WANG, C., Lu, L., y Chen, C. 2008. Evaluating firm technological innovation capability under uncertainty. Technovation, 28, 349-363.

YAM, R., Cheng, J., Guan, Kit F., Pun, K., y Tang, E. 2004.An audit of technological innovation capabilities in Chinese firms: some empirical findings in Beijing, China. Research Policy, 33, | |23-I| 40. 